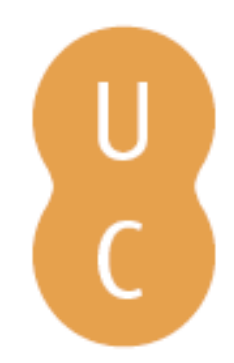

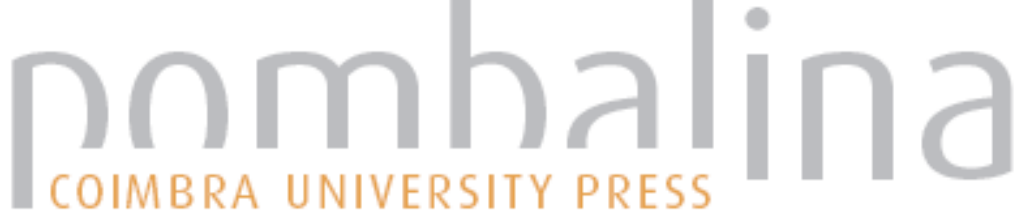

\section{Heating and ignition from firebrand piles}

Autor(es): $\quad$ Hakes, R. S. P.; Salehizadeh, H.; Weston-Dawkes, M. J.; Gollner, M. J.

Publicado por: Imprensa da Universidade de Coimbra

URL

persistente: URI:http://hdl.handle.net/10316.2/44604

DOI: $\quad$ DOI:https://doi.org/10.14195/978-989-26-16-506_87

Accessed : $\quad$ 26-Apr-2023 07:39:52

A navegação consulta e descarregamento dos títulos inseridos nas Bibliotecas Digitais UC Digitalis, UC Pombalina e UC Impactum, pressupõem a aceitação plena e sem reservas dos Termos e Condições de Uso destas Bibliotecas Digitais, disponíveis em https://digitalis.uc.pt/pt-pt/termos.

Conforme exposto nos referidos Termos e Condições de Uso, o descarregamento de títulos de acesso restrito requer uma licença válida de autorização devendo o utilizador aceder ao(s) documento(s) a partir de um endereço de IP da instituição detentora da supramencionada licença.

Ao utilizador é apenas permitido o descarregamento para uso pessoal, pelo que o emprego do(s) título(s) descarregado(s) para outro fim, designadamente comercial, carece de autorização do respetivo autor ou editor da obra.

Na medida em que todas as obras da UC Digitalis se encontram protegidas pelo Código do Direito de Autor e Direitos Conexos e demais legislação aplicável, toda a cópia, parcial ou total, deste documento, nos casos em que é legalmente admitida, deverá conter ou fazer-se acompanhar por este aviso.

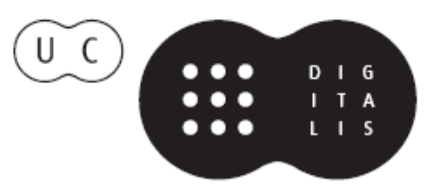




\section{ADVANCES IN}

\section{FOREST FIRE RESEARCH}

\section{8}

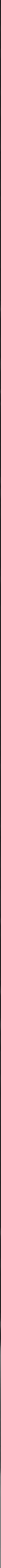




\title{
Heating and Ignition from Firebrand Piles
}

\author{
R.S.P. Hakes; H. Salehizadeh; M.J. Weston-Dawkes; M.J. Gollner* \\ University of Maryland, College Park, Department of Fire Protection Engineering. 3106 J.M. \\ Patterson Bldg., College Park, Maryland 20742, United States, \{mgollner@umd.edu*\}
}

\begin{abstract}
Smoldering firebrands, also known as burning embers, cause the majority of structural ignitions in the wildland-urban interface (WUI). Firebrands can be lofted several kilometers from the main firefront and smolder for several hours before causing ignition of vegetation or structural components, such as decks or roofs. Previous studies on ignition by firebrands have focused primarily on either vegetative fuels, large scale ignition of solid fuels (e.g. wood materials), or ignition by individual firebrands. This study focuses on small-scale heating and ignition phenomena by measuring heat fluxes from piles of firebrands and connecting heating to ignition conditions. In order to capture the heating from glowing firebrand piles and understand the ignition process of WUI fuels, small-scale experiments were conducted using laboratoryfabricated cylindrical wooden firebrands. Heating by firebrand piles was de-coupled from the ignition process by initially studying heating from firebrands on an inert surface. The influences of firebrand diameter, firebrand pile mass, and wind were explored. Firebrand diameter was found to have little effect on heating, while firebrand pile mass had a moderate effect, and wind had a large effect on measured heat flux. Piles did not produce higher heat fluxes as pile mass increased. Instead, larger piles heated a larger area of the fuel for an increasingly longer duration as pile mass increased. Based on the results from heating experiments, two firebrand pile masses were studied under three wind conditions to understand the process governing the transition to ignition of a recipient fuel. Video recordings indicated a qualitative description of the transition from smoldering to flaming. Flaming ignition of the recipient fuel occurred soon after deposition of the firebrand pile for $16.2 \mathrm{~g}$ of smoldering firebrands, with a minimum critical wind speed of $1.0 \mathrm{~m} / \mathrm{s}$ required to cause transition to flaming. No smoldering of the recipient fuel occurred when only $5 \mathrm{~g}$ of firebrands were deposited.
\end{abstract}

Keywords: Firebrand ignition, Firebrands, Burning embers, Wildland-urban interface

\section{Introduction}

Over the past several decades, the area burned by wildland-urban interface (WUI) fires has increased drastically (Caton 2016). WUI fires are wildland fires that burn into developed urban areas that either abut or intermix with the wildland. The result of the increasing severity of WUI fires is that thousands of structures are lost annually to wildland fires across the globe (Grishin 2014, NICC 2017). The majority of structures are ignited in WUI fires by firebrands (Cohen 2008, Maranghides 2013, Maranghides 2015) which can travel several kilometers ahead of the main firefront (Maranghides 2013). Smoldering firebrands typically accumulate into piles (Suzuki 2017a). The smoldering piles can cause ignition of the recipient fuel on which they deposit, such as a deck or roof, which may ultimately cause full structure ignition.

Although firebrands cause the majority of structural ignitions, the heating conditions leading to ignition and causing the transition from smoldering to flaming ignition are not well understood. There is little previous work at the small-scale that explores the ignition of solid WUI fuels due to piles of smoldering firebrands. Previous work has focused primarily on ignition of vegetative fuels by individual firebrands (Ellis 2013, Ellis 2015, Manzello 2006a, Manzello 2006b, Urban 2018), or fullscale ignition of structural components (Manzello 2012, Manzello 2017). This study focuses on smallscale heating and ignition phenomena by measuring heat fluxes from piles of firebrands and connecting heating under varying wind speeds to ignition conditions. 


\section{Methods}

Two phases of experiments were conducted to quantify critical heating conditions preceding ignition and describe the transition from smoldering to flaming ignition of solid WUI fuels. For Phase I, an experimental set-up was developed to quantitatively measure the heat flux from firebrand piles under ambient conditions. For Phase II, an additional set-up was constructed to investigate the effects of wind, both on heat flux and ignition behavior. Measurements of heat flux were made on an inert surface in order to decouple the heating from the firebrand pile from ignition and to better characterize the thermal conditions critical for ignition.

For both heat flux and ignition experiments, firebrands were fabricated from cylindrical birch wooden dowels oven-dried at $103^{\circ} \mathrm{C}$ to $0 \pm 0.5 \%$ moisture content (MC) per ASTM D4442 (ASTM 2015). Firebrands were fabricated by exposing all of the wooden dowel pieces to be used for a single pile to a propane flame in a wire-mesh basket, based on a method in (Manzello 2006a). The propane flame was extinguished after the majority of the wood began flaming. Firebrands were allowed to burn freely in air until flaming combustion ceased and all firebrands were glowing. Glowing firebrands were deposited on the experimental set-up. Firebrands of length $25.4 \mathrm{~mm}$ were used at three different initial diameters, $6.35 \mathrm{~mm}, 9.52 \mathrm{~mm}$, and $12.7 \mathrm{~mm}$, for Phase I. Because diameter was found to have little effect on heating, only $12.7 \mathrm{~mm}$ firebrands were used in Phase II.

For heat flux experiments in both Phase I and II, the experimental set-up was instrumented with either an array of sixteen thin-skin calorimeters (TSCs), a single water-cooled heat flux gauge (WCHFG), or a combined array with the WC-HFG at the center of the TSC array. TSCs provided a spatial characterization of the heat flux at different points beneath the firebrand pile, while the WC-HFG provided temporally-resolved heat flux measurements at the center of the pile. Heat flux gauges of both types were placed in the center of a ceramic fiber inert insulation board, flush with the surface of the board.

Phase II ignition experiments were conducted over oriented-strand board (OSB), a common building materials in the United States. Ignition experiments and heat flux experiments with applied wind were conducted in front of a wind tunnel with a constant speed of $1.84 \mathrm{~m} / \mathrm{s}$ as that was a condition determined to repeatably cause ignition. Two firebrand pile masses, $7.9 \mathrm{~g}$ and $16.2 \mathrm{~g}$ of $12.7 \mathrm{~mm}$ firebrands, were used for Phase II tests.

\section{Results and discussion}

Heat flux tests under ambient conditions were conducted to determine the influence of firebrand diameter and firebrand pile mass on heat flux. Results from the tests at ambient conditions were used to choose a firebrand diameter and two pile sizes to compare under varied wind speeds for both heat flux tests and ignition tests. Wind was used for ignition tests because ignition of the solid fuels tested by smoldering firebrands could not be achieved without wind. In this study, TSCs were used to understand the spatial distribution of heat flux beneath a firebrand pile and to determine whether heat flux was evenly distributed through the pile.

Results from the TSC array found high variability in the heat fluxes measured in different parts of the pile. This variability is likely due to variability in individual pieces of wood and in the smoldering combustion of wood. Although the WC-HFG provides a good measure of a single point in the pile, the TSC array gives a more comprehensive view of the area heated by the firebrand pile and the extent of radiation from the pile to the rest of the inert surface. Figure shows the heat flux variability in a winddriven test at two instances: $1 \mathrm{~min}$ and $10 \mathrm{~min}$ after firebrands were deposited. Early in the test, heat flux is highest at the side of the firebrand pile facing the wind, but the areas of highest heating change later in the test. 

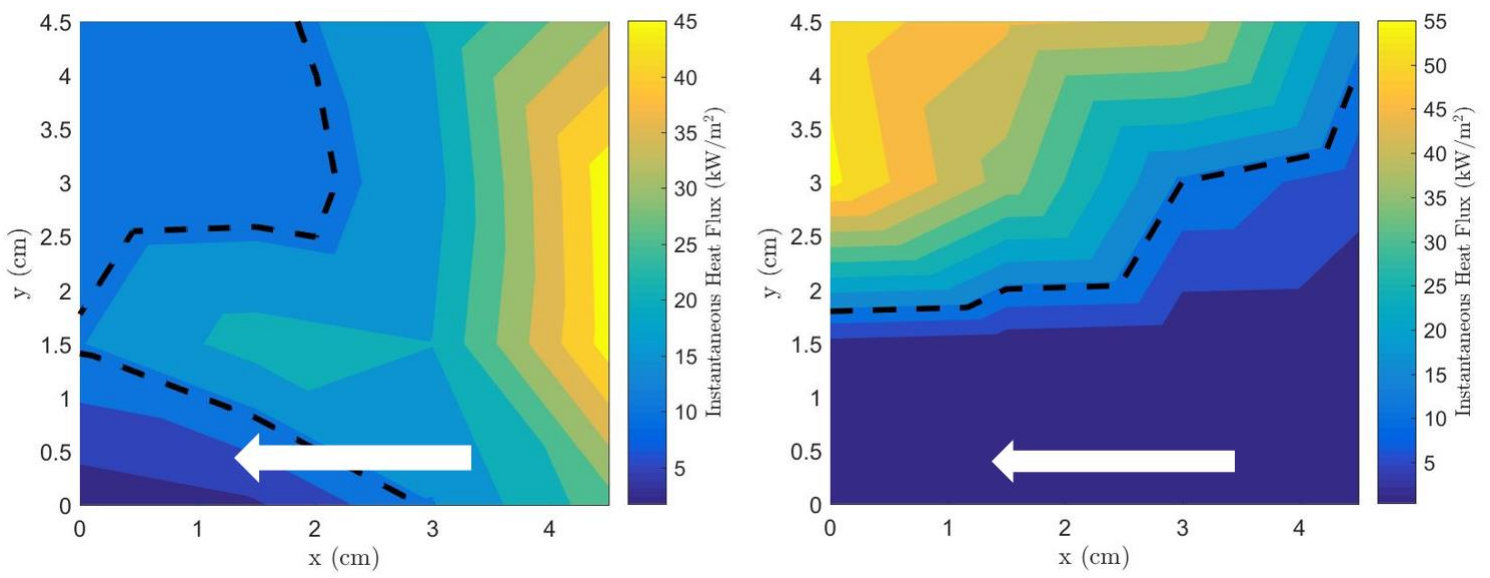

Figure 1 - Spatial distribution of heat flux under $1.84 \mathrm{~m} / \mathrm{s}$ wind for a $16.2 \mathrm{~g}$ deposited mass pile of $12.7 \mathrm{~mm}$ firebrands at (left) 1 min and (right) 10 min into test. Wind direction: right to left.

The effects of firebrand diameter and firebrand pile size (measured as the mass of glowing firebrands deposited on the test set-up) were compared using the peak heat flux and the net heat imparted by the firebrand pile to the sensors. The peak heat flux was taken to be the maximum heat flux value achieved within a given test repetition and averaged over five test repetitions. Net heat released was taken as the area under the heat flux curve over the full length of the test and averaged over five test repetitions.

Firebrand diameter had a negligible effect on both the peak heat flux and the net heat released. Previous studies using individual firebrands have found that firebrand size (measured here as the diameter of a single firebrand) made a significant difference in whether vegetative fuels ignited. Results for the firebrand pile differ as individual firebrands in the pile can interact through re-radiation. The re-radiation behavior, rather than firebrand size, is suspected to dominate the heat transfer from piles as the firebrand pile is a noncontiguous ignition source (Babrauskas 2003). Additionally, tests with a single firebrand placed on a TSC found that nearby (at a distance of $0.5-1.5 \mathrm{~cm}$ ) uncovered sensors received an average of one third of the peak heat flux received by the sensor directly in contact with the firebrand, despite the fact that uncovered sensors are subject to higher convective cooling losses. These results indicate the importance of radiation for the firebrand heating and ignition problem.

The peak heat flux for all firebrand piles was higher than the peak heat flux reached by a single firebrand; however, peak heat flux did not vary much with firebrand pile size, as shown in Figure .

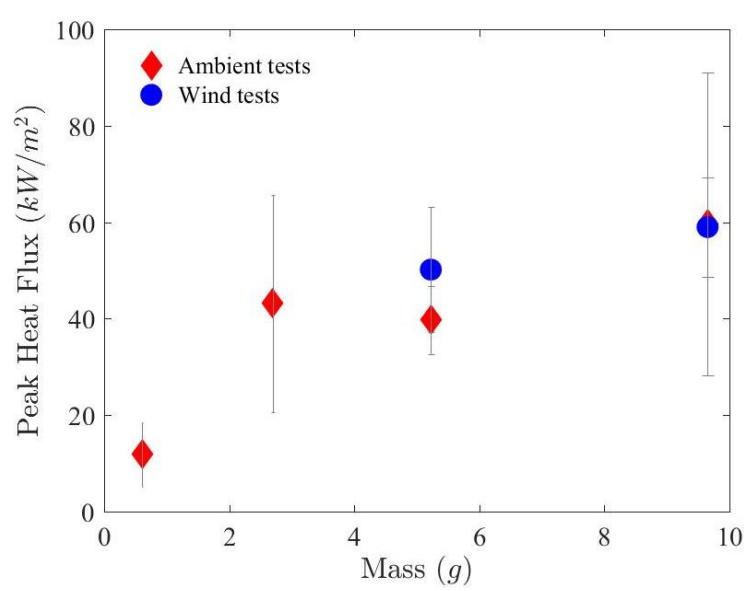

Figure 2 - Peak heat flux as a function of deposited mass for $12.7 \mathrm{~mm}$ piles under ambient and wind conditions. The smallest mass, $0.6 \mathrm{~g}$, is a single firebrand. Peak heat flux increases from an individual firebrand to a pile, but steadies with pile mass. A wind speed of $1.84 \mathrm{~m} / \mathrm{s}$ has little effect on the peak heat flux. Error bars are the standard deviation of the tests. 
The net heat imparted by the firebrand pile increased linearly with increasing pile size and with applied wind, as shown in Figure. This result is expected as a larger pile sizes produced higher sustained heat flux values throughout the tests. Heat fluxes under wind were sustained at higher heat flux values than ambient heat fluxes, but dropped off more quickly as forced flow provided increased convective cooling to the pile.

Although both peak heat flux and net heat released provide descriptions of the pile heating, neither captures the dependency on time of critical ignition conditions. Critical ignition conditions are often given as a steady heat flux or temperature value sustained over a critical exposure time.

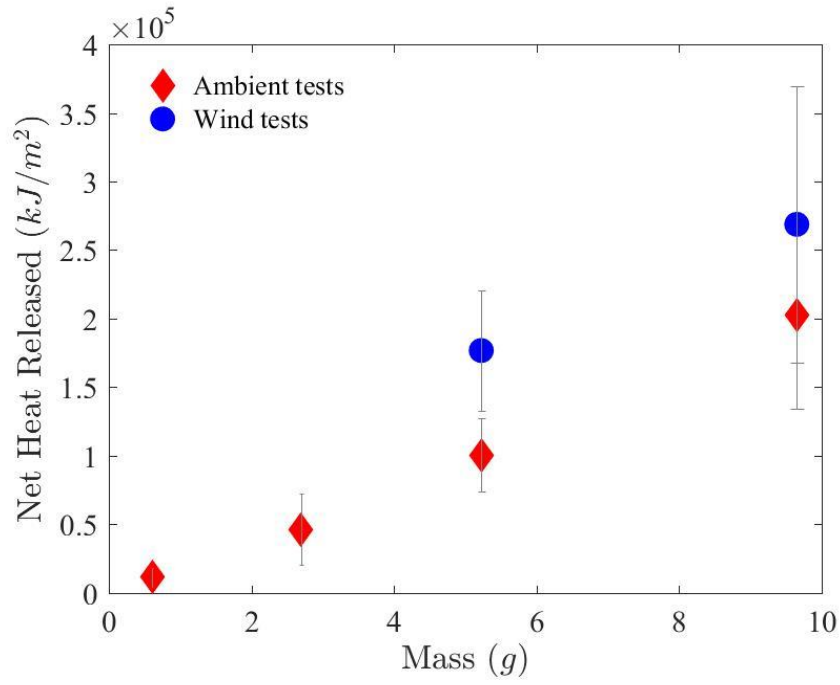

Figure 3 - Net heat released as a function of deposited mass for $12.7 \mathrm{~mm}$ diameter firebrands. The smallest mass, 0.6 $\mathrm{g}$, is a single firebrand. Net heat released increases linearly with increasing pile mass under ambient conditions. The addition of wind, $1.84 \mathrm{~m} / \mathrm{s}$, causes higher net heating values. Error bars are the standard deviation of the tests.

Ignition of the recipient fuel only occurred when it was exposed to $16.2 \mathrm{~g}$ of glowing firebrands, the larger of the two pile sizes tested. No ignition occurred under ambient conditions, and ignition by the $16.2 \mathrm{~g}$ firebrand pile required a minimum $1.0 \mathrm{~m} / \mathrm{s}$ wind speed. Figure shows ignition location for a $16.2 \mathrm{~g}$ pile of firebrands deposited on a sheet of OSB. For all tests that ignited, ignition occurred within a few minutes of the firebrand pile being deposited. The recipient fuel initially smoldered and then transitioned to flaming ignition.

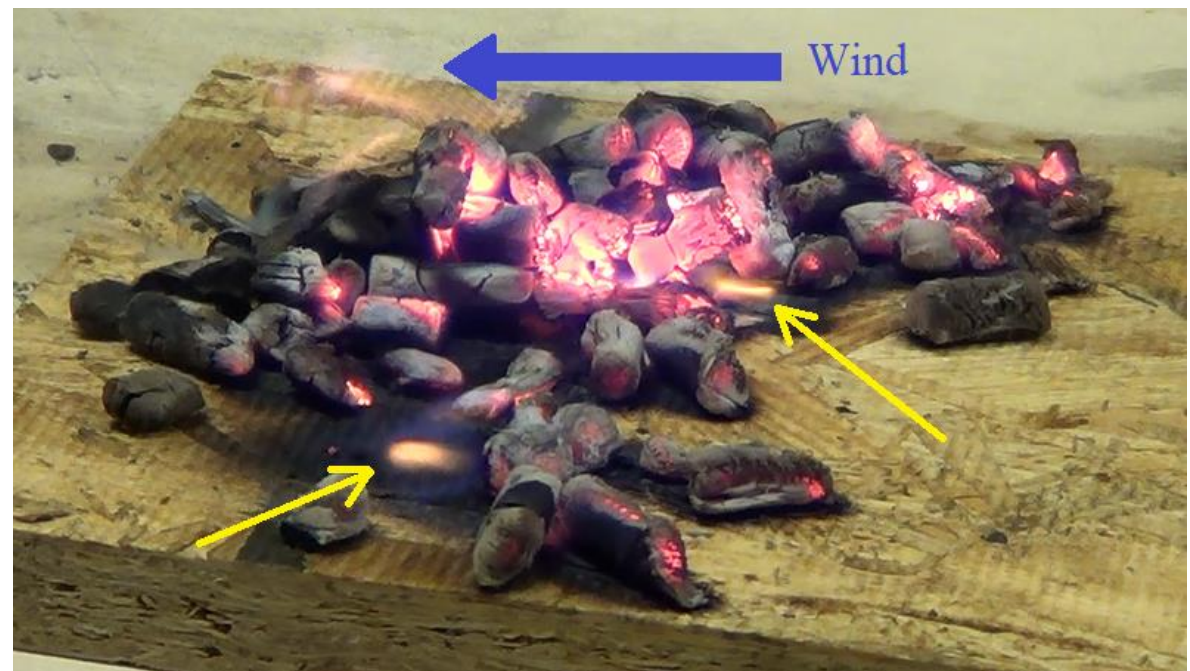

Figure 4 - Ignition of recipient $O S B$ fuel exposed to $16.2 \mathrm{~g}$ smoldering firebrands two minutes into test under $1.84 \mathrm{~m} / \mathrm{s}$ wind. Arrows indicate areas of fuel ignition (as opposed to flaming of firebrands). 


\section{Conclusions and future work}

A methodology for measuring heat fluxes from firebrand piles has been applied under ambient and forced flow conditions. Firebrand diameter was found to have little effect on the heat flux from a firebrand pile, likely indicating that the heat transfer in firebrand piles is dominated by re-radiation and reheating rather than individual firebrand characteristics. Heat flux conditions immediately preceding ignition have been measured to indicate how conditions preceding ignition relate to the occurrence of ignition. Wind was found to play a critical role in the ignition of dense, thermally thick WUI fuels. Wind tests show that critical heat fluxes for ignition are changed when exposed to forced flow.

\section{Acknowledgements}

The authors would like to thank Alicea Fitzpatrick, Erin Griffith, Alison Davis, Jessen Oey, Evan Sluder, and Seth Lattner for their assistance with laboratory experiments, and Jiann Yang, Nelson Bryner, and the NIST WUI group for advice and support. This research was funded by the United States Department of Commerce, National Institute of Standards and Technology Fire Research Grant Program under financial assistance awards 60NANB15D358, 70NANB16H284 and 70NANB17H288.

\section{References}

American Society of Testing and Materials (2015) ASTM D4442: Standard test methods for direct moisture content measurement of wood and wood-based materials.

Babrauskas V (2003) 'Ignition Handbook.' (Fire Science Publishers: Issaquah)

Caton SE, Hakes RSP, Gorham DJ, Zhou A, Gollner MJ (2016) Review of pathways for building fire spread in the wildland urban interface part I: Exposure conditions. Fire Technology 53(2), 429-473.

Cohen JD, Stratton RD (2008) Home destruction examination: Grass Vallet Fire, Lake Arrowhead, CA. USDA Forest Service, Pacific Southwest Region Technical Paper R5-TP-026b. (Vallejo, CA)

Ellis PFM (2013) Firebread characteristics of the stringy bark of messmate (Eucalyptus obliqua) investigated using non-tethered samples. International Journal of Wildland Fire 22, 642-651.

Ellis PFM (2015) The likelihood of ignition of dry-eucalypt forest litter by firebrands. International Journal of Wildland Fire 24, 225-235.

Grishin AM, Filkov AI, Loboda EL, Reyno VV, Kozlov AV, Kuznetsov VT, Kasymov DP, Andreyuk SM, Ivanov AI, Stolyarchuk ND (2014) A field experiment on grass fire effects on wooden constructions and peat layer ignition. International Journal of Wildland Fire 23, 445-449.

Manzello SL, Cleary TG, Shields JR, Yang JC (2006a) Ignition of mulch and grasses by firebrands in wildland-urban interface fires. International Journal of Wildland Fire 15, 427-431.

Manzello SL, Cleary TG, Shields JR, Yang JC (2006b) On the ignition of fuel beds by firebrands. Fire and Materials 30, 77-87.

Manzello SL, Suzuki S, Hayashi Y (2012) Enabling the study of structure vulnerabilities to ignition from wind driven firebrand showers: A summary of experimental results. Fire Safety Journal 54, 181-196.

Manzello SL, Suzuki S (2017) Experimental investigation of wood decking assemblies exposed to firebrand showers. Fire Safety Journal 92, 122-131.

Maranghides A, McNamara D, Mell W, Trook J, Toman, B (2013) A case study of a community affected by the Witch and Guejito fires: Report \#2 - evaluating the effects of hazard mitigation 
actions on structure ignitions. National Institute of Standards and Technology Technical Note NIST TN 1796. (Gaithersburg, MD)

Maranghides A, McNamara D, Vihnanek R, Restaino J, Leland C (2015) A case study of a community affected by the Waldo Fire - Event timeline and defensive actions. National Institute of Standards and Technology Technical Note NIST TN 1910. (Gaithersburg, MD)

National Interagency Coordination Center (2017) Wildland fire summary and statistics annual report.

Suzuki S, Manzello SL (2017) Experiments to provide the scientific-basis for laboratory standard test methods for firebrand exposure. Fire Safety Journal 91, 784-790.

Urban JL, Zak CD, Fernandez-Pello C (2018) Spot fire ignition of natural fuels by hot aluminum particles. Fire Technology 54, 797-808. 